\title{
Inna Bjelajeva, Niepodstawowe nazwy barw w języku polskim, czeskim, rosyjskim i ukrainskim, Warszawa 2005, ss. 277
}

Książka Inny Bjelajevej wpisuje się znakomicie w ten nurt badań językoznawczych, w którym wiele uwagi poświęca się problemom kategoryzacji rzeczywistości odwzorowanej na płaszczyźnie onomazjologicznej i semantycznej języka, a zwłaszcza podobieństwom i różnicom językowego obrazu świata różnych społeczności. Zakodowana w poszczególnych językach konceptualizacja pojęć składających się na sieć znaczeniową kategorii nazw barw jest szczególnie interesującym polem poszukiwań. $Z$ jednej strony uniwersalny mechanizm zjawiska fizycznego i podobieństwo możliwości percepcyjnych, związanych $\mathrm{z}$ wyposażeniem biologicznym człowieka, warunkuje pewne tożsamości pojęciowo-językowej kategoryzacji, z drugiej strony odmienny filtr kulturowy może spowodować znaczne różnice w ukształtowaniu kategorii. W przypadku języków społeczności tak bliskich kulturowo jak te, które są przedmiotem badań Inny Bjelajevej, możemy się spodziewać wielu zbieżności i niezbyt wielu odrębności. Tym bardziej interesujące są wyniki porównawczej analizy semantycznej nazw barw w czterech językach słowiańskich (reprezentujących grupy wschodnią i zachodnią), jeśli chodzi o obszary i zakres przejawiania się różnic. Trzeba tutaj podkreślić, że autorka - obecnie wykładowca języka polskiego i czeskiego na ukraińskim Uniwersytecie Przykarpackim - jest szczególnie predysponowana do prowadzenia badań porównawczych. Łączy bowiem naukową pracę językoznawczą z praktyczną znajomością języków słowiańskich jako osoba - o czym czytamy w nocie biograficznej - wychowana w rodzinie rosyjsko-ukraińskiej i absolwentka polonistyki oraz bohemistyki Uniwersytetu Lwowskiego im. Ivana Franki. Na kształt pracy, a zwłaszcza owocny wybór metodologii badań (nawiązującej do teorii synchronicznej analizy słowotwórczej i kognitywistycznych koncepcji sieci znaczeniowych) miał też zapewne wpływ kilkuletni kontakt badaczki z językoznawcami Wydziału Polonistyki Uniwersytetu Warszawskiego, przede wszystkim z profesor Krystyną Waszakową, promotorem jej doktoratu.

Jak zaznacza autorka we Wstępie (s. 7), przedmiotem jej analizy są niepodstawowe nazwy barw, odnoszące się do odcieni barw o nazwach podstawowych, którym w literaturze lingwistycznej poświęcono wiele uwagi, podczas gdy nazwy 
niepodstawowe, $\mathrm{w}$ tym rozbudowany, zwłaszcza $\mathrm{w}$ językach słowiańskich, typ przymiotników derywowanych od rzeczowników (szmaragdowy, malinowy itp.), były analizowane najczęściej na marginesie rozważań poświęconych nazwom różnicującym podstawowe spektrum barw. Badaczkę interesują przede wszystkim rzeczownikowe podstawy formacji słowotwórczych (szmaragd, malina itp.), wskazujące na rzecz lub zjawisko w roli „wzorca motywującego" daną niepodstawową nazwę barwy. Porównanie tych wzorców w poszczególnych językach, przedstawione w rozdziale 6. opracowania, pokazuje zarazem różnice akceptowanych kulturowo obiektów, poprzez które postrzegane są barwy w danej społeczności. Nawiązując do prac autorów poruszających tę tematykę na gruncie polskim (A. Zaręba, M. Szabłowska, R. Tokarski), czeskim (F.-R. Brüggemann), rosyjskim (P. Hill, A. Vasilevič) i ukraińskim (O. Dzivak, O. Visoc'kij), I. Bjelajeva proponuje własne ujęcie, konstruując system grup znaczeniowych nazw wzorców (s. 175 i n.), które motywują zarówno tworzenie nazw barw, jak i rozumienie ich znaczenia w poszczególnych językach. Jak można się domyślać, źródłem obiektów i cech reprezentujących te wzorce są sfery przyrodniczego uniwersum: rośliny, zwierzęta, człowiek, minerały, żywioły, części kosmosu, a także sfery artefaktów: barwniki, metale, artykuły spożywcze, materiały budowlane, przedmioty i substancje użytkowe. Zakres wykorzystania tych kategorii w konceptualizacji „przestrzeni koloru” w poszczególnych językach oraz wybór nazw konkretnych obiektów jako wzorców motywujących niepodstawowe nazwy barw jest przedmiotem analizy, także statystycznej (por. s. 173-191).

Trzeba tutaj podkreślić, że choć autorkę interesuje zasób niepodstawowych nazw barw we współczesnych językach słowiańskich i ich synchroniczna analiza słowotwórcza, to analiza wzorców motywujących odzwierciedla raczej punkt widzenia historycznego konceptualizatora, dla którego związek znaczeniowy między daną niepodstawową nazwą barwy (np. karmazynowy) a nazwą wzorca motywującego (karmazyn) był przejrzysty i żywo odczuwany. Autorka świadomie skupia się na analizie tego właśnie związku, odzwierciedlonego w strukturze derywowanych nazw barw, rezygnując z uwzględniania „wzorca prototypowego” (zob. s. 166), tj. obiektu, który „użytkownicy języka mają na myśli, posługując się nazwą odcienia barwnego o zatartym związku z etymologicznym wzorcem motywującym" (tamże). Dodajmy, że istnienie wzorca prototypowego, odmiennego od wzorca motywującego, nie wyklucza czytelnego związku między nazwą odcienia barwnego a podstawą słowotwórczą (nazwą wzorca motywującego) w świadomości współczesnych użytkowników języka. Uwzględnienie relacji między wzorcem motywującym a prototypowym dałoby pełniejszy wgląd w kulturowy obraz świata barw; wymagałoby jednak, jak zauważa sama autorka (s. 168), analizy wielu użyć tekstowych nazw, a także badań wykraczających poza ramyjęzyka, przede wszystkim psychologicznych.

Rozdział poświęcony wzorcom motywującym jest końcowym rozdziałem opracowania, prezentującym ważne uszczegółowienie obrazu pól semantycznych 
nazw barw w porównywanych językach i zarazem modelu konceptualizacji i rozumienia pojęć obejmujących „przestrzeń koloru”. Badaczka konstruuje ten model w rozdziałach 3-5, stawiając sobie za cel usystematyzowanie pełnego zasobu nazw oznaczających odcienie barw według ogniskowych nazw barw podstawowych w poszczególnych językach (cz. I, rozdz. 3); przedstawienie w postaci „modeli sieciowych" struktur znaczeniowych poszczególnych podkategorii nazw (cz. II, rozdz. 4); porównanie sieci znaczeniowych w obrębie ognisk i opis rozszerzeń kategorii, a także przedstawienie schematu relacji znaczeniowych między nazwami barw ogniskowych wyrażanych przez nazwy ich odcieni (cz. II, rozdz. 5).

W opisie porównawczym kategorii niepodstawowych nazw barw Bjelajeva zastosowała metodologię kognitywną (zob. założenia teoretyczne przedstawione w rozdz. 2), sięgając przede wszystkim do koncepcji ukazujących związek kategorii poznawczych z językiem: modelu „kategorii radialnej” G. Lakoffa, której rozszerzeniem jest „model sieciowy” R. Langackera. Autorka przyjmuje, że konceptualizacja nazw barw odbywa się poprzez łańcuch wzajemnie powiązanych ze sobą „domen” ( „domenę” definiuje za Langackerem jako „strukturę konceptualną, względem której dana jednostka jest definiowana" - s. 26). Na przykład, struktura znaczeniowa nazwy malinowy jest określana względem podstawowej domeny barwy czerwonej, która ma nad sobą nadrzędną domenę - przestrzeń koloru, oraz domeny podrzędnej-wzorzec motywujacy: kolor dojrzatych malin. Nie tylko jednak wzorzec motywujący różnicuje nazwy odcieni barwy czerwonej; w kształtowaniu sieci znaczeniowej ważne są dodatkowe wymiary „obrazowania”, np. rozjaśnienie przez barwę białą (pol. poziomkowy), przyciemnienie przez barwę czarną (pol. wiśniowy, bordo, buraczkowy), udział innych barw ogniskowych: pomarańczowej (pol. ceglasty, ognisty), różowej (pol. amarantowy, malinowy), fioletowej (pol. buraczkowy, purpurowy) itp. Bjelajewa przyjmuje, że w całościowym modelu kategorii podstawowej (np. czerwony) niepodstawowe nazwy barw tworzą „wewnętrzną ramę znaczeniową”, wpisaną w ogólny „wyidealizowany model kognitywny" kategorii podstawowej, której rozszerzenia są oparte na podobieństwie niektórych cech odcieni barwy podstawowej do prototypu (elementu centralnego) kategorii, w przypadku odcieni barwy czerwonej- do koloru krwi (zob. s. 30-31). Przy czym stopień podobieństwa do prototypu wyznacza miejsce danej nazwy w strefie jądra lub na peryferiach kategorii.

Należy tutaj odnotować pewną niekonsekwencję metodologiczną: w identyfikacji centralnego elementu kategorii autorka bierze pod uwage „wzorzec prototypowy” (kolor krwi), a nie - „wzorzec motywujący” (w przypadku pol. czerwony - odmienny od wzorca prototypowego), ustalając następnie wzorzec motywujący (a nie prototypowy) dla poszczególnych nazw odcieni (np. malina dla określenia malinowy) i stopień jego podobieństwa do prototypu całej kategorii. Jest to podstawa wnioskowania o strukturze znaczeniowej kategorii. Problemem 
jest tutaj zmienność prototypów i ich relacja do wzorców motywujących nazwy. Warto w tym kontekście podkreślić, że trudności w analizie znaczeniowej kategorii nazw barw mogą się wiązać z przyjmowanymi przez badaczy ograniczeniami perspektywy do płaszczyzny synchronicznej; sama autorka zwraca uwagę na te ograniczenia (s. 32-33). Problematyczne jest także wyznaczenie granicy między tym, co współczesne (obecne w świadomości aktualnych użytkowników języka), a tym, co należy do przeszłości; trudność ta ujawnia się już w ustaleniu zasobu nazw odcieni określonej barwy podstawowej na danym etapie rozwoju języka, jeśli bierze się pod uwagę - jak to uczyniła Bjelajeva - głównie materiał ze słowników rejestrujących leksykę używaną w dłuższym okresie, wykraczającym zazwyczaj poza ramy „współczesności”.

Jak pokazuje szczegółowe porównanie sieci znaczeniowych w poszczególnych językach, przeprowadzone w rozdziałach 4. i 5. omawianego opracowania, różnice w kulturowo zinterpretowanym obrazie spektrum barw ujawniają się nie tylko w wyborze poszczególnych obiektów lub ich atrybutów jako wzorców motywujących nazwy barw, ale także w ilości wariantów w zakresie poszczególnych nazw odcieni, w obecności lub braku pewnych wymiarów postrzegania tych odcieni i zarazem składników znaczeniowych nazw (jak np. 'przyciemnienie tonu podstawowego', 'świecenie', 'nasycenie' itp.). Różnice te nie niwelują, oczywiście, zasadniczego podobieństwa pojęciowo-językowej kategoryzacji przestrzeni koloru w porównywanych językach (por. Aneks III na końcu omawianego opracowania), podobieństwa uwarunkowanego wspólnotą fizycznych i kulturowych podstaw procesów postrzegania barw i kodowania tych procesów w języku.

W opisie sieci znaczeniowych nazw barw w czterech językach słowiańskich Inna Bjelajeva skupiła się na systemowym i syntetycznym przedstawieniu wzajemnych relacji w zakresie podstawowych zróżnicowań onomazjologiczno-semantycznych, tworząc niejako kanwę dla wyników badań uszczegółowiających. Cennym uzupełnieniem jej precyzyjnie i czytelnie nakreślonej matrycy byłoby wpisanie $\mathrm{w}$ ten modelowy obraz kategorii materiału językowego zaczerpniętego $\mathrm{z}$ wypowiedzi w danym języku (zwłaszcza peryferyjnych, także indywidualnych tworów słownikowych, ujawniających dalsze różnicowanie kolorystycznego spektrum), z uwzględnieniem tekstowych konotacji poszczególnych nazw barw; konotacji motywujących różnego rodzaju przeniesienia cech związanych $\mathrm{z}$ domeną koloru na inne domeny. Potrzebę badań interdyscyplinarnych (zwłaszcza psycholingwistycznych) sygnalizuje sama autorka; badania diachroniczne oraz socjolingwistyczne ( $z$ uwzględnieniem regionalizmów) na materiale poszczególnych języków słowianskich dostarczyłyby także innych danych do analiz porównawczych, dla których cenne opracowanie Inny Bjelajevej będzie miało znaczenie podstawowe. 